\title{
ON XENOFLUSTRA VOIGTI N. GEN., N. SP. (BRYOZOA, CHEILOSTOMATIDA, BUGULOIDEA) A NEW FLUSTRINE BRYOZOAN FROM THE SOUTH WESTERN ATLANTIC OCEAN
}

SOBRE XENOFLUSTRA VOIGTI N. GEN., N. SP. (BRYOZOA, CHEILOSTOMATIDA, BUGULOIDEA) UN NUEVO BRIOZOO FLUSTRINO DEL ATLÁNTICO SUDOCCIDENTAL

Hugo I. Moyano G. ${ }^{1}$

\section{RESUMEN}

Durante la realización de la expedición alemana LAMPOS a los archipiélagos del Arco de Scotia, en abril de 2002, se dragaron dos zooarios flustriformes negruscos de más de $10 \mathrm{~cm}$ de alto. Su estructura es tanto buguloide como flustroide, sus grandes ovicelas y su carencia de avicularias permiten describirlos como un nuevo género y una nueva especie.

Palabras clave: Bryozoa, Buguloidea, Flustra, Xenoflustra voigti n. gen., n. sp., Atlántico sudoccidental, Arco de Scotia.

\section{ABSTRACT}

During the German LAMPOS cruises on April 2002, from the Arc of Scotia Archipelagos, two large (10-15 cm high) dark flustrine zoaria were collected. These turned out to be a new genus and a new species. Zoaria were slightly calcified and had no avicularia. In its general structure this genus and species deserve a taxonomic place into the Bugulidean Cheilostomatida.

Key words: Bryozoa, Bugoloidea, Flustra, Xenoflustra voigti n. gen, n. sp., South western Atlantic ocean, Scotia Arc archipelagos. 


\section{INTRODUCTION}

Flustrine, Scruparine, Cellularine, Buguline and Cellariinie bryozoans represent a large set of flexible species that form an important part of the bryozoan faunas inhabiting subantarctic and Antarctic waters (Hasting 1943, Moyano 1991, 1995, Hayward 1995). In antarctic waters until 1995 were recorded 264 cheilostomatous bryozoan species (Hayward 1995) from which not less than 82 (31\%) exhibit flexible forms. This figure is actually higher due to the existence of flustrine flexible species like Adelascopora secunda, A. jeqolqa (Microporellidae) and Kymella polaris (Hippoporinidae) that have evolved from families or genera, with normally rigid and encrusting zoaria, to become flustriform species. On the other hand, in subantarctic Atlantic and Pacific waters off the southern tip of South America and in Kerguelen waters of the Indian Ocean have been recorded not less than 50 species having flexible zoaria out of $>200$ bryozoan species in those areas (Hastings 1943, d'Hondt \& Redier 1977, Moyano 1982, 1991) including Flustrapora magellanica (Microporidae).

Since 1980 several new records of known or unknown flexible species have been added. Among these standed up those described by López-Gappa (1982). This author proposed two new genera and three new species: Neoflustra dimorphica, Austroflustra australis and A. gerlachi, all recorded in subantarctic waters.

Hayward (1995) added the new species Chartella notialis belonging to a genus previously unknown in subantarctic areas. Moyano (1998) introduced the new name Isoseculiflustra rubefacta for an antarctic flustrine species having wide reddish zoaria erroneously atributed to Isoseculiflustra angusta (Kluge) also an antarctic species with slender and yellowish zoaria living in deeper waters. Later on, samples taken in the continental slope near Cape Horn yielded 18 flexible species out of 56 (Moyano 2000).

Among these stand up tiny flexible cribrimorphan zoaria belonging to the new family Polliciporidae and to the new genus and species Pollicipora fucata Moyano 2000. Other interesting finding was Adelascopora stellifera, the first subantarctic extant member of the flustrine microporellidan genus Adelascopora.
Ten years ago, on April 2002, the German $\mathrm{R} / \mathrm{S}$ Polarstern gathered a large collection of bottom samples containing bryozoans during the "LAMPOS" Polarstern Cruises to the Scotia Arc archipelagos which, starting and ending in Punta Arenas (Chile), reached the South Shetland Islands. A preliminary observation and analysis of the bryozoan samples revealed an abundant and speciose "flustran" fauna containing a clear cut separated subantarctic and Antarctic species.

The aim of this paper is to describe, illustrate and discuss specimens of flustrine deep blue or black zoaria showing a mixing of zoarial and zooidal characters recalling genera like Flustra s.l. Himantozoum, Dendrobeania and Caulibugula.

\section{MATERIALS AND METHODS}

The material studied consist of two large (16$17 \mathrm{~cm}$ high) and one small $(10 \mathrm{~cm}$ high) colonies obtained by the $\mathrm{R} / \mathrm{S}$ vessel Polarstern during the "LAMPOS" Polastern Cruises to the Scotia Arc archipelagos in the following stations:

1) PS61/150-106.04.0213:27; 54 30,66' S; $56^{\circ} 8,58^{\prime}$ W; 286 m; Agassiz trawl

2) PS61/153-106.04.0218:12; $54^{\circ} 33,23$ ' S; $56^{\circ} 10,12$ ' W, 296,8 m; bottom trawl. Burdwood Bank (off South Falkland Islands)

Colonies were initially fixed in ethanol 96\% but later on were kept in 70\% ethanol.

SEM microphotographies were taken from gold-coated dried specimens previously washed with a very diluted $\mathrm{NaClO}$ solution.

\section{RESULTS}

Xenoflustra n. gen.

Diagnosis: Zoarium flustrine, light-calcified, flexible, alga-like, unilaminar, profusely branched and fixed to substrate by means of a rhizoodial tuft. Zooids forming alternating rows in wich each zooid originates from a forked proximal basal part and ends in a distal partially free distal ascending part; distal and lateral zoecial borders provided with non-articulated spines. No avicularia. Ovicel hyperstomial, symmetrical not a kenozooid, well developed, with a calcified entooecium.

Type species. Xenoflustra voigti sp. n. 


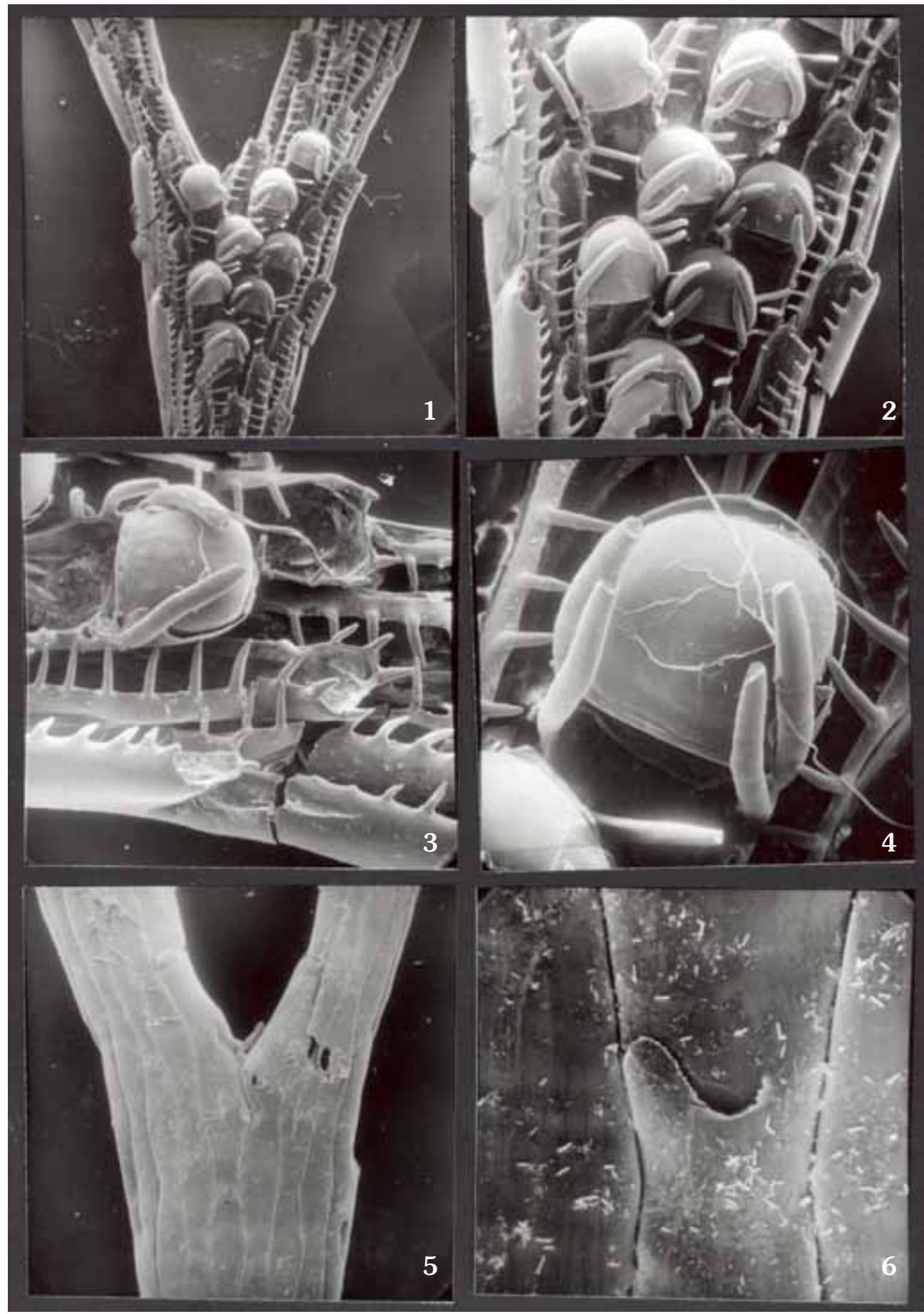

Fig. 1. (above-left) x 15. Zoarial bifurcation in frontal view showing ovicells and marginal spines Fig. 2. (above right) x 30 Central frontal part of fig 1 . Note the marginal and ovicellar spines. Fig. 3. (middle left) $x 60$ Lateral view of a zoarium showing the two types of spines.

Fig. 4. (middle right) x 95 Frontal view of an ovicell exhibiting the frontal-proximal shield both types of spines. Fig. 5. (bottom left) x 15 Abfrontal view of fig. 1. Note limits between elongated zooids. Fig. 6. (bottom right) x 20 basal view of one zooid. 
Etymology: Genus: From the Greek xenos meaning rare, strange and from the genus Flustra due to its zoarial structure; the species name after the oustanding German Bryozoologist the late Dr. Professor Ehrhard Voigt (Hamburg)

\section{Xenoflustra voigti n. sp.}

Diagnosis: Zoarium flexible. Flustrine, dichotomously and densely ramified, rami long and narrow, unilaminated, pluriserial, having from five to nine longitudinal zooecial rows between bifurcations; color dark brown in ethanol (96\%) and lighter in ethilic alcohol (70\%). Autozooids longer tan wide, ending in 4 disto-lateral tiny spines, with 5 - 10 sub marginal external unarticulate acute lateral spines and a wide and membranous operculum; each zooid with a partially free distal end overlaping the distal zooid. No avicularia. Ovicell hyperstomial, almost spherical, closed by the zooidal operculum, provided with 4 spines larger and thicker tan those of ordinary zooids.

Types: As indicated in materials and methods, deposited in Museo de Zoología de la Universidad de Concepción MZUC-UCCC.

Holotype: 35465

Paratype: 35466.

\section{REMARKS}

At first glance this species looks like a flustra having narrow and thick branches. A closer examination reveals the existence of long zooids having marginal and well spaciated and uprightdirected marginal spines recalling some beaniids. Ovicells recall those in Scrupocellariidae and other cellularine families. The structure of zooids in having a free distal end mimics Beania zooids and also in having marginal not articulated spines, but Beania lacks conspicous hiperstomial ovicells. Similar characters appear in some species of the Bugulinidae genus Camptoplites, however, in it avicularia are abundant and complex whereas they are completely lacking in Xenoflustra gen. nov. In summary, Xenoflustra voigti is provisionally put into the Bugulidae although lacking avicularia, but it is worth to remember that in some Bugula species like B. longissima Busk and B. neritina Linnaeus, avicularia are altogether wanting.

\section{ACKNOWLEDGEMENTS}

The author is indebted to the Alfred Wegener Institut that organized the LAMPOS cruises on board the R/V "Polarstern" making posible the study of a bryozoan collection from the Scotia Arc archipelagos. The author is also grateful for the help of Michael Schrödl of the Zoologische Staatssammlung München, and Maritza Palma former postgraduate student at Universidad de Concepción, Chile, researchers who were on board and physically sorted out the samples studied. Finally the author thanks the anonymous referees and the editors of this volumen for improving the form and contents of this work.

\section{LITERATURE CITED}

Hastings, A. B. 1943. Polyzoa (Bryozoa) I. Scrupocellariidae, Epistomiidae, Farciminariidae, Bicellariellidae, Aeteidae, Scrupariidae. Discovery Report 22:301

Hayward, P. J. 1995. Antarctic Cheilostomatous Bryozoa. Oxford University Press Inc. New York

Hondt, J. L. d' 1990. Adelascopora secunda subsp charcoti, subsp. Nov., nouveau bryozoaire cheilostome (Microporellidae) de l'océan glacial arctique. Bulletin de la Société zoologique de France (Francia), 115 (3): 263-270

Hondt, J. L. d' \& L. Redier 1977. Bryozoaires récoltés lors des campagnes d'été 1972 et 1974 aux iles Kerguelen (Ctenpstomes, Cheilostomes sauf Cribrimorphes), Entoproctes). Comité National Français des Recherches Antarctiques, 42: 215-236

López- Gappa J. J. 1982 Bryozoa collected by the German Antarctic Expedition 1980-81. Flustridae. Meteor Forsch. Ergeb. Reihe D, 35: 35-41

Moyano G. H. I. 1982. Magellanic Bryozoa: Some ecological and zoogeographical aspects. Marine Biology, 67: 81-96

Moyano G. H. I. 1991 Bryozoa Marinos chilenos VIII: Una síntesis zoogeográfica con consideraciones sistemáticas y la descripción de diez especies y dos géneros nuevos. Gayana Zoología (Concepción): 55 (4): 305-389 
Moyano G. H. I. 1996 On a new species of Flustridae from Antarctica (Bryozoa Cheilostomata) Gayana Zoología (Concepción): 60 (2) 161-172 Moyano G. H. I. 1999. Magellan Bryozoa: a review of the diversity and of the subAntarctic and Antarctic zoogeographical links. Scientia Marina, 63(1): 219-226

Moyano G. H. I. 2000. Bryozoa from the Magellanic Continental Slope near Capehorn: An unexpected Collection: 239-304. In: Herrera Cubilla A. \& J. B. C. Jacson (eds.) Proceeding of the $11^{\text {th }}$ International Bryozoology Association Conference. Smithsonian Tropical Research Institute. Balboa, República of Panamá
Moyano G. H. I. 2002. Bryozoa from oceanic south eastern Pacific Island: Diversity and Zoogeography: 229-238. In: P. N. Wyse Jacson, C. Buttler \& M. Spencer Jones (eds.) Bryozoan Studies 2001, Swets \& Zellinger, Lisse, Netherlands

Moyano G. H. I. 2005. Bryozoa de la Placa de Nazca con énfasis en las Islas Desventuradas. Ciencia y Tecnología del Mar (Valparaíso) 28 (1): 75-90

Moyano G. H. I. 2005. Scotia Arc bryozoans: a narrow bridge between two different faunas. Scientia Marina, 69 (supl. 2): 103-112 
H. MOYANO 